\title{
Identifying Early Neolithic Settlements in the Šumadija Region of Serbia Through Combined Pedestrian Survey and Archaeological Geophysical Prospection
}

\author{
Miroslav Kočića,c, Bryan Hanks ${ }^{\mathrm{a}^{*}}$, Marija Kaličanin Krstićb, \\ Marc Bermann", Petra Basar ${ }^{a}$, Michael Mlyniec ${ }^{a}$ \\ ${ }^{a}$ University of Pittsburgh, Department of Anthropology, 3302 WWPH Pittsburgh, PA 15260, USA \\ ${ }^{b}$ Institute for the Protection of Cultural Monuments, Kragujevačkog Oktobra 184, 34000, Kragujevac, Republic of Serbia \\ 'Archaeological Institute of Serbian Academy of Sciences and Arts, Knez Mihailova 35/4, 11000 Belgrade, Republic of Serbia
}

\section{ARTICLE INFO}

\section{Article history:}

Received: $25^{\text {th }}$ January 2020

Accepted: $8^{\text {th }}$ July 2020

\section{DOI: http://dx.doi.org/10.24916/iansa.2020.1.1}

\section{Key words}

Early Neolithic

Starčevo culture

geophysical prospection

pedestrian survey

\begin{abstract}
A B S TRACT
The development of Neolithic lifeways represented fundamental shifts in social organization and human-environment relationships within local ecological settings. An understanding of this process in the Balkans peninsula has remained intriguing and challenging in the broader context of European prehistory. Evidence for Neolithization processes in the Balkans begins around the seventh millennium BC in the south-east at important tell sites such as Nea Nikomedia and Sesklo where rectangular house structures and other elements of the "Neolithic package" strongly resemble those of the Levant. The northern zone of the Balkans peninsula, however, presents a different situation, with small flat sites with intrusive later occupation making patterns of early Neolithization difficult to discern. This paper reports recent field research in Central Serbia (Šumadija region, Gruža River valley) where Early Neolithic occupation related to the Starčevo culture has been found at the newly identified site of Kneževac through systematic pedestrian survey, artifact spatial analysis, and near surface archaeological geophysics. The results of this research are discussed in the context of other Early Neolithic settlement evidence in the region, along with their implications for understanding early agricultural populations in Central Serbia.
\end{abstract}

\section{Introduction}

Research on the Early Neolithic Starčevo culture in Central Serbia began in the 1950s (Garašanin, 1954; Gavela, 1961). A new phase of international cooperation was carried out from 1968-1971 (McPherron and Srejović, 1988) at the site of Grivac (Figure 1), where the earliest stage of the settlement was identified with pit features containing Starčevo artifacts (considered "Proto Starčevo" by the excavators, Bogdanović, 2004). These excavations were followed in the 1970s by additional research at the settlements of Divostin and Kusovac by an international project directed by D. Srejović and A. McPherron (McPherron and Srejović, 1988). Site stratigraphy at Divostin indicated that the earliest occupation dated to the Early/Middle Neolithic and was characterized by Starčevo culture pottery and other artifact types characteristic

*Corresponding author. E-mail: bkh5@pitt.edu of this period. Five above-ground domestic structures, pits of various dimensions and shapes, some interpreted as "pitdwellings", and open-air fire installations were identified (Divostin, subphases Ia-c).

Eleven radiometric dates of different contexts associated with the Divostin I phase were produced (McPherron and Srejović, 1988). A re-analysis and calibration of these dates indicates that Early/Middle Neolithic occupation began by 6,000 cal $\mathrm{BC}$ and that the site might have been abandoned by around 5,800 cal BC (Borić, 2009). The site was then reoccupied by 4,700 cal $\mathrm{BC}$ (Vinča culture occupation) and then re-abandoned around 4,540 cal BC. Based on this chronology, a potential occupation gap existed of nearly one millennium between the end of the Starčevo occupation and the beginning of the Vinča culture occupation. This chronological phasing is intriguing when considering the interpretations of the original excavators who emphasized that some domestic structures associated with Phase II were 
found exactly above earlier Starčevo "pit-house" features (McPherron and Srejović, 1988). Unfortunately, due to heavy weathering of the early Phase I deposits, and subsequent intrusive occupation of the Divostin II phase, Phase I does not provide much additional information on the organization of early Starčevo culture settlements.

Important new information about the Early Neolithic in the Central Balkans was generated in the 1980s by excavations at the site of Blagotin, situated in the Morava River valley (Stanković and Leković, 1993). There were large scale excavations completed in the 1980s at the sites of Paljevine and Grobnice, which are now located in the submerged zone of the Gruža Lake. Unfortunately, these sites (450 square meters of excavated area) were not published and the associated field reports are not available. The most recent archaeological excavation in the Morava River valley is the large-scale project at Drenovac; however, this is a multiperiod site with a very significant Vinča stratigraphic layer overlying the earlier phases/occupations at the site (Perić, 2016). Apart from these sites, other reported Early Neolithic sites are covered by later Vinča phase occupation and have only been subject to very limited excavation. This situation challenges any interpretation of the spatial organization of Early Neolithic sites in central Serbia and any attempts to reconstruct the important Starčevo to the later Vinča transition.

Currently, one of the best sources of information on the organization of Starčevo communities in Serbia is the salvage excavation at the site of Jaričište I (Marić, 2013). A large expanse of this site was exposed through excavation, revealing concentrically grouped subterranean pit-houses and details of their construction, use, and maintenance (Marić, 2013). The site of Jaričište I indicates that Starčevo pit-houses were durable constructions, supporting interpretations that these were fixed, permanent occupations rather than ephemeral camp sites in the landscape. These early sites, therefore, represent important early domestic loci for examining emergent Neolithization trends in the Balkans. However, much more research is needed to better understand these early occupations, the community organization and regional settlement patterning, and use of local resources.

It is important to note that there are indeed many similarities among Starčevo-Körös-Criș settlements across the central Balkans, including their spatial organization. Important field research, including archaeological geophysics, pedestrian survey, and stratigraphic excavation, has been completed at several Early Neolithic sites in Hungary and Romania and provide an important foundation of comparative data for interpreting early settlement sites in central Serbia (Bánffy, 2000; Green and Lawson, 2018; Bánffy, 2013). However, there also exist strong regional characteristics and patterns and it is difficult to make direct comparisons of central Serbian sites to contemporaneous sites in the Panonian Basin, which are over 400 kilometres away and in a completely different geomorphological zone. More research, therefore, is needed to examine such settlement patterning in Serbia and to address the many open questions regarding these Early Neolithic sites. In response to this, in 2016, the University of Pittsburgh and the Institute for the Protection of Cultural Monuments in Kragujevac, Serbia, initiated a new program of cooperation focusing on systematic pedestrian survey coupled with multi-method archaeological geophysical surveys in the Šumadija region of central Serbia. To date, a total area of $102.47 \mathrm{~km}^{2}$ has been surveyed through systematic field walking (Kočić, 2019, doctoral dissertation research) and five Neolithic settlements have been investigated with multi-method geophysical surveys (total of $52 \mathrm{ha}$ ) through the Šumadija Regional Geospatial Archaeology Project (SRGAP). In the following sections, we discuss research at the site of Kneževac, which was identified through pedestrian survey and surface collection and spatial analysis by M. Kočić in 2017. Subsequent multiinstrument geophysics was conducted at the site by SRGAP in 2018 to further characterize the archaeological potential of the site. Further investigation and ground truthing will be conducted at Kneževac in 2020.

\section{Pedestrian survey methods}

The methods employed for the regional scale pedestrian survey followed those associated with North American field archaeology traditions, which have been long influenced by a comparative focus on the emergence of sedentism and animal and plant domestication processes in different locations around the world. Reconstruction of settlement patterning as a way of interpreting demographic processes, catchment zones, and settlement hierarchies has been a common element in such studies (Carneiro, 1970; Earle, 1997).

Historical property inheritance practices within the Šumadija region have led to the splitting of land parcels, resulting in virtually no large, open tracts of land to survey. The field methods utilized in the regional scale pedestrian survey drew on previously published methods (MacNeish et al., 1975; Hirth, 1980; Feinman and Nicholas, 1990) and more recent statistical approaches to sampling sites with dense concentrations of surface artifacts (Drennan and Peterson, 2011). The survey team maintained an objective target of approximately 50 ha of coverage per day but this varied depending on the sites encountered and density of associated surface artifacts.

Most of the survey zone was made up of open tilled fields and field walking was done over the course of a calendar year and multiple seasons. This ensured that the surface visibility of artifacts was excellent in fields that had been recently tilled or left fallow through the winter. The survey team was comprised of a line of five members who walked together systematically while spaced $20 \mathrm{~m}$ apart. Handheld GPS units were utilized to record the beginning and end of each transect. The primary collection units were 1-hectare cells, which were further divided into sub-cell collection units of $20 \times 20 \mathrm{~m}$. These units were sampled using a $1.81 \mathrm{~m}$ radius "dog-leash" collection circle, which provided a $10 \mathrm{~m}^{2}$ 


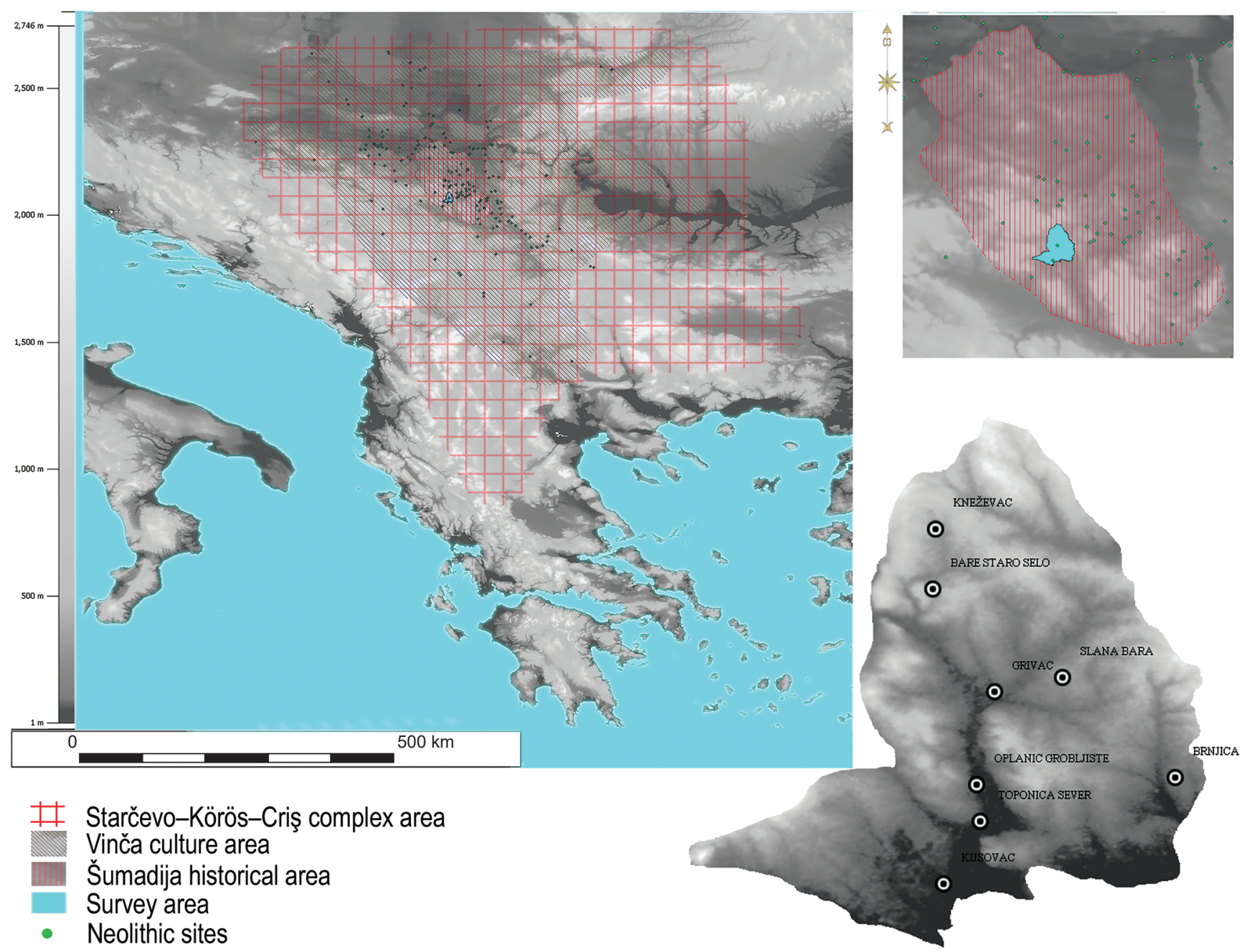

Figure 1. Map showing geographic zones for Early to Late Neolithic archaeological sites within the Balkans region and location of regional survey and associated Neolithic sites.

sample, thereby limiting the total number of artifacts that needed to be collected for spatial analysis (Drennan and Peterson, 2011).

In total, 27,754 artifacts were collected during the regional survey and this included full coverage of two large Neolithic settlements (Grivac and Kusovac, each approximately $35 \mathrm{ha}$ ) with evidence of Early to Late Neolithic occupation (Starčevo and Vinča) and a third site, Kneževac (approximately 6 ha in size), which displayed only Early Neolithic occupation (Starčevo) (Figure 1). In the following sections, we detail the results of research at Kneževac as this was the only Early Neolithic site identified with no later intrusive Neolithic occupations.

\section{The Kneževac settlement}

This site was largely undocumented in the scientific literature other than from verbal reports of Neolithic potsherds being found in fields by local villagers (Bogdanović, 1983).
No subsequent archaeological survey or test excavations were undertaken in the area to try and locate the site. The regional pedestrian survey in 2017 identified a spatial cluster of Starčevo type pottery near the northernmost part of the historical Kneževac village. The site is situated along a gentle slope that represents the first outcrops of the foothills of the Rudnik Mountain. There is one active freshwater spring within the site, another in the immediate vicinity, and two small creeks running on both sides. The soil on the site is vertisol-smonitza, which is also found in the immediate vicinity of the site, and the adjacent creek areas. The surrounding higher flatlands are comprised of the cambisol gajnjača soil type, which has a relatively low agricultural production yield. Even today, higher flatland crops are more dispersed than in the lower parts of the valley where the soils are more productive.

A total of 436 artifacts were recovered at Kneževac through pedestrian survey and surface collection, with pottery $(75 \%)$, lithics $(15 \%)$ and daub $(10 \%)$ being represented (Figures 2 and 3). Artifact density over the site was surprisingly high 

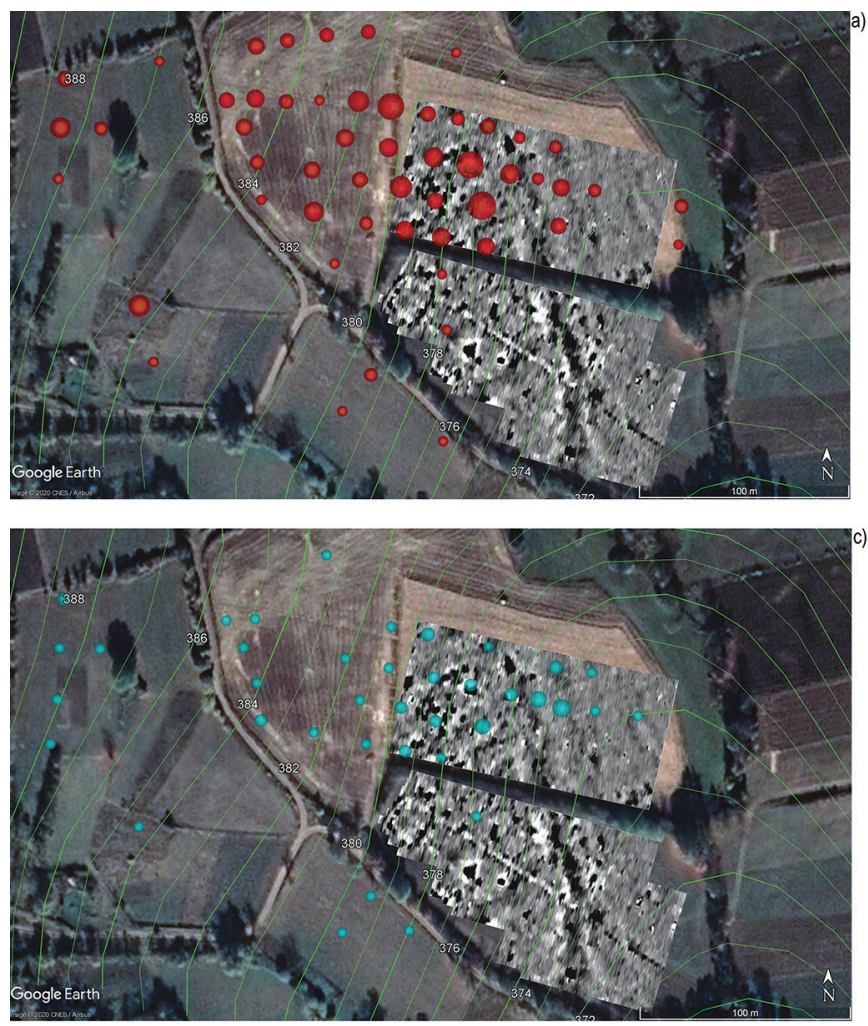

a) Distribution of Starčevo period pottery densities per 10 square meter "dog-leash" collection circle

- min. 1 sherd

max. 17 sherds

c) Distribution of Starčevo

lithic artefacts densities

per 10 square meter

"dog-leash" collection circle

- min. 1 artefact

max. 7 artefacts
Figure 2. A - distribution and density of Starčevo ceramic sherds across Kneževac site area collected within "dog-leash" samples per artifact count; B - distribution and density of Starčevo ceramic sherd weights across Kneževac site area collected within "dog-leash" samples per artifact weight; $\mathrm{C}$ - distribution and density of lithic artifacts across Kneževac site area collected within "dog-leash" collection circles per artifact count. for a Starčevo period settlement (median of $\sim 12$ artifacts per 10 sq. meter dog leash circle). The estimated area of the entire site is approximately 6 ha, as measured both by the size of the surface artifact scatters and geophysical prospection. The central zone of the site contains what are tentatively interpreted as a circle of pit anomalies. It is likely that these represent Starčevo architectural elements known as pit houses (Figures 2 and 4). This arrangement is similar to the site of Jaričište I, as discussed above. This circular organization could be indicative of the "communal" site type organization suggested for Early Neolithic sites in the Levant (Kuijt, 2006). Soil coring with a $10 \mathrm{~cm}$ diameter a)

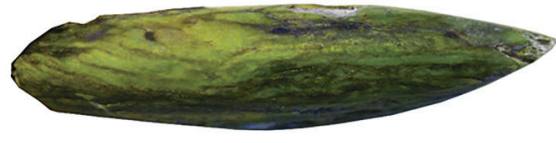

d)

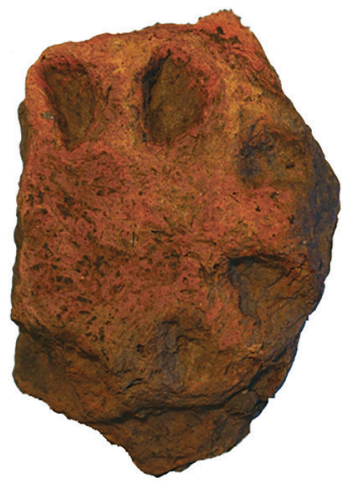

b)
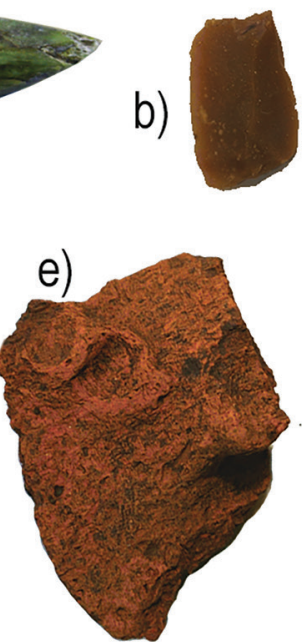

$7 \mathrm{~cm}$

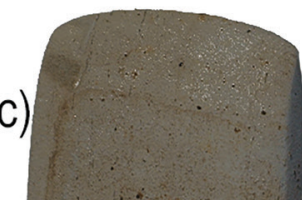

Figure 3. Artifacts collected during pedestrian survey over the Kneževac site: a - Schist polished adze from the central area of Kneževac; b- Honey coloured, non-local chert from Kneževac; $\mathrm{c}$ - Mudstone polished axe from the southeastern area of the site; d - Pottery fragment exhibiting rosetta circular ornamentation from Starčevo area at Kusovac site; e - Pottery fragment showing same circular rosetta ornamentation from the central area of Kneževac. 
auger indicated that the stratigraphy of the site was less than $1 \mathrm{~m}$ in depth between the subsurface magnetic anomalies. Soil coring was not undertaken within the areas of the geomagnetic anomalies at the time of the surveys.

Surface artifact densities at the site likely correlate with settlement layout as the greatest density of ceramic sherds were found adjacent to and between clustered magnetic anomalies. Another apparent pattern was seen in the location of flint working and other possible lithic industries. The presence of two large clusters of lithic artifacts could reflect communal activities by the inhabitants of this settlement (Figures 2 and 3). Lithic artifacts recovered from the site demonstrate substantial variability in flint source material, including raw materials that are absent from the rest of the valley. This is well represented by the recovery of a schist adze (Figure 3 ).

\section{Geophysical survey methods}

Multi-method geophysical surveys are preferred to single method prospection as different methods will respond to different dimensions of surface and subsurface properties, which may help to identify specific anomalies associated with human activities and anthropogenic change in the local environment (Kvamme et al., 2006). Geophysical survey at Kneževac utilized three methods: (i) high resolution single axis fluxgate gradiometry with a Bartington 601-2 dual probe instrument; (ii) low frequency electromagnetics with a GF Instruments CMD Mini-Explorer; and (iii) surface soil magnetic susceptibility with a Bartington MS2 meter combined with a MS2K Surface Sensor probe. These methods were selected to provide a rapid form of site characterization and potential identification of prehistoric subsurface features (e.g. pits, pit-houses, trenches or ditches), traces of burnt features (e.g. kilns, hearths, burned structures), and enhanced soils (e.g. midden deposits, animal pen areas, domestic structures).

\subsection{Fluxgate gradiometry}

The Bartington Grad 601-2 can be utilized to detect minute variations in the earth's magnetic field due to archaeological and geophysical subsurface features (parameters set at \pm 0.03 to $100 \mathrm{nT}$ ). The fluxgate gradiometry method has been found to be highly useful in identifying subsurface pits, ditches or trenches, and fired or burnt features such as hearths, kilns and ovens (Gaffney and Gater, 2003; Aspinall et al., 2008). It offers a rapid method for quickly assessing archaeological sites for magnetic responses. Parallel transects were walked with this instrument using fiberglass standing rods for path alignment within the established $20 \times 20 \mathrm{~m}$ grids Measurements were taken with transects spaced every $1 \mathrm{~m}$ with 160 measurements collected along each transect (every $12.5 \mathrm{~cm}$ ). Data were downloaded to a laptop computer and processed with Terrasurveyor, a dedicated processing software for geophysical instruments. Minimal processing was necessary to correct data, with destriping, despiking, interpolation of the $\mathrm{Y}$ axis (resulting in a resolution of $0.50 \times 0.125 \mathrm{~m}$ ), and data clipping used to enhance contrast.

Two survey blocks were completed over the site (Figure 4). The northern rectangular survey block was $20 \times 60 \mathrm{~m}$ and comprised $0.84 \mathrm{ha}$. This area contained 33 principal monopolar positive anomalies that, prior to data clipping, ranged from 1.0 to $11.0 \mathrm{nT}$. These are interpreted as representing possible subsurface pit house and/or pit features. Additionally, 2 dipolar simple anomalies were encountered that, prior to data clipping, ranged from -25 to $45 \mathrm{nT}$ and one additional simple dipolar anomaly that ranged from -58 to $64 \mathrm{nT}$. These anomalies are interpreted as possible subsurface burned areas or high temperature archaeological features. In addition, we distinguished a possible trench feature in the western area of the survey and a possible enclosure zone running northwest to southeast across the centre of the survey.

A second survey block was completed to the south and was of an irregular form that comprised 1.28 ha. This area contained 46 monopolar positive anomalies that, prior to data clipping, ranged from 1.0 to $11.0 \mathrm{nT}$. These are interpreted as representing possible subsurface pit house and/or pit features. Additionally, 5 dipolar simple anomalies were encountered that, prior to data clipping, ranged from -27 to $10 \mathrm{nT}$. These also are interpreted as possible subsurface burned areas or high temperature archaeological features. One additional dipolar anomaly was encountered that ranged from -100 to $100 \mathrm{nT}$ and likely represents an intrusive ferrous object of a modern or historic date. A possible trench feature was also identified in the western area of the survey, a possible enclosure zone running northwest to southeast across the eastern zone of the survey (seen also in the northern survey zone), and a negative linear feature running from northwest to southeast across the survey zone that is likely generated by a modern dirt track and related compacted soil.

Clusters of anomalies were identified in each survey zone. These two areas are detailed in Figure 5 (Area A and Area B). Previous archaeological excavations of Starčevo settlements have identified similar clusters of pit houses, pits, and high temperature features (McPherron and Srejović, 1988; Marić, 2013). Additional geophysical methods (low frequency electromagnetics and magnetic susceptibility of surface soils) were completed in Area A to produce complimentary data for interpreting the fluxgate gradiometry survey and surface collection of artifacts.

\subsection{Low frequency electromagnetic (EM) method}

Apparent conductivity and magnetic susceptibility changes in the soil were mapped using the low frequency electromagnetic (EM) method (CMD Mini-Explorer, GF Instruments). The low-frequency EM system measures subsurface variations of both geophysical properties simultaneously by operating on the principle of electromagnetic induction under low induction values $(<300 \mathrm{kHz})$ (Thiesson et al., 2009). Even though lowfrequency EM systems, also known as Slingram or FDEM (frequency-domain electromagnetic induction) instruments, have been used in archaeology since the 1960s (Tabbagh, 


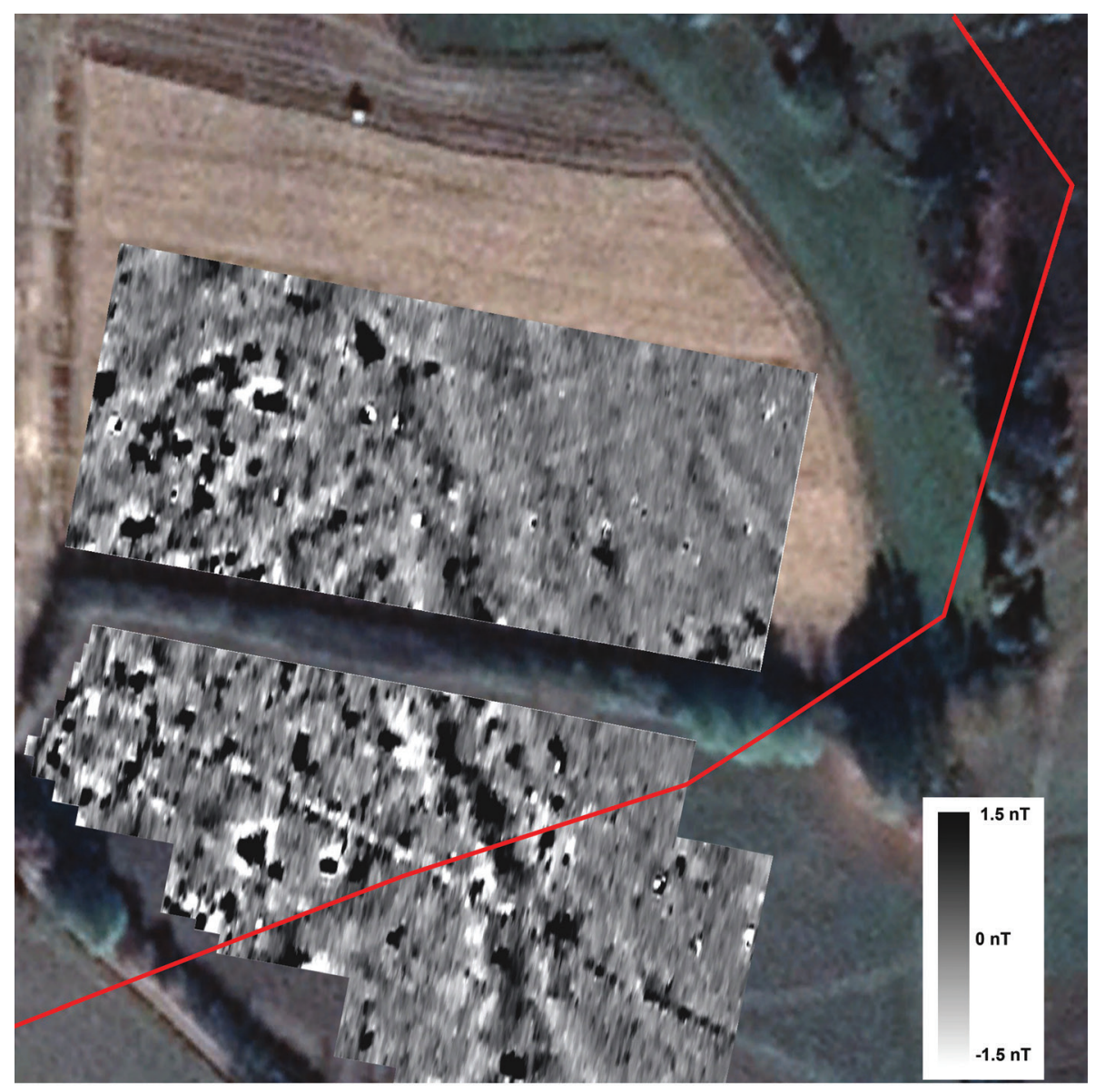

Figure 4. Upper - Grey-scale plots of fluxgate gradiometer surveys (red line denotes spatial boundaries of collected surface artifacts); Lower - interpretation of magnetic gradient anomalies.

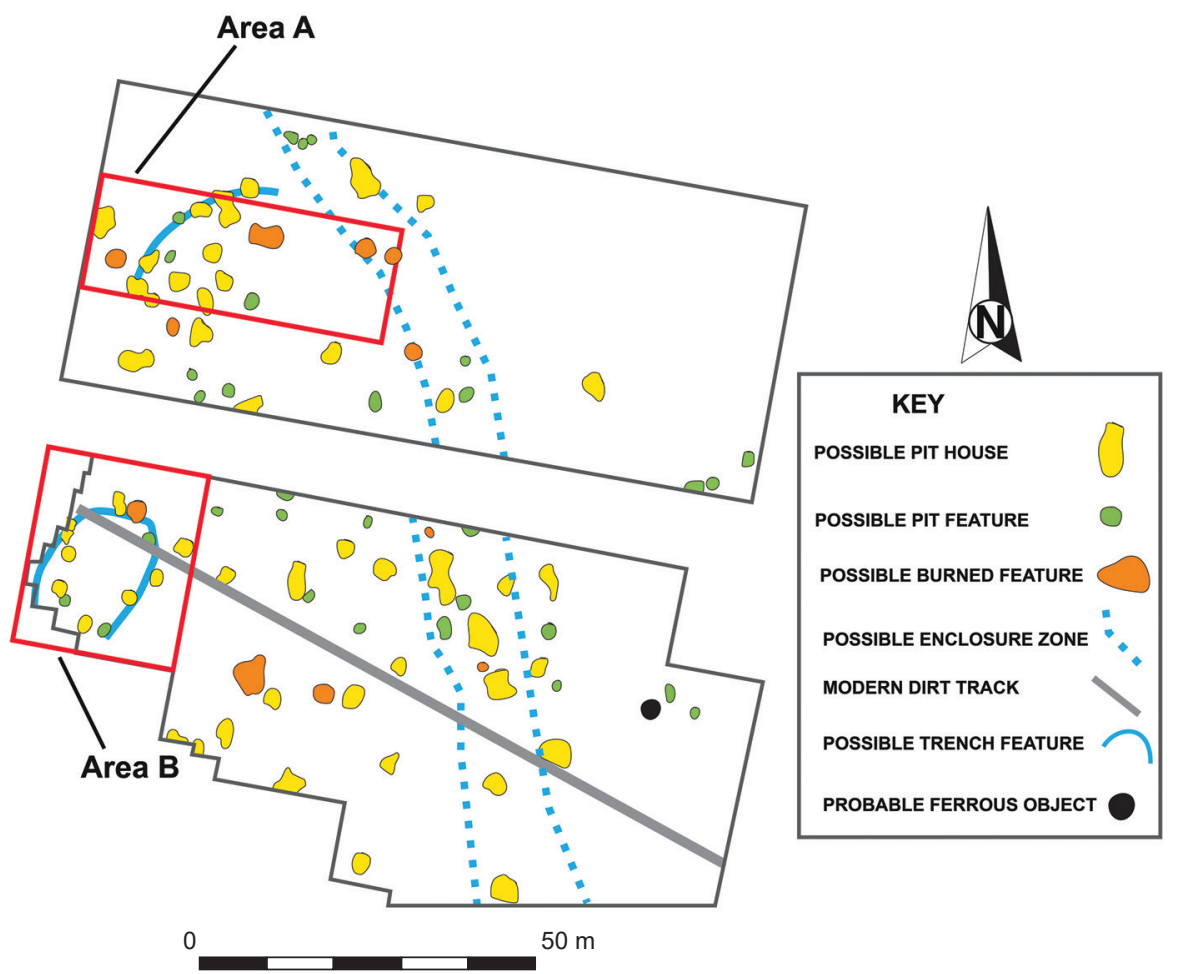

1986), the multi-sensor CMD Mini-Explorer has recently been introduced to European archaeological prospection (Bonsall et al., 2013; Wunderlich et al., 2015; Basar, 2018).
The quadrature component of this instrument reflects apparent electrical conductivity measured in millisiemens per meter (mS/m) (Abdu et al., 2007). Electrical conductivity 
Figure 5. Grey-scale plots of Area A and Area B from fluxgate gradiometer surveys with interpretations of primary anomalies.
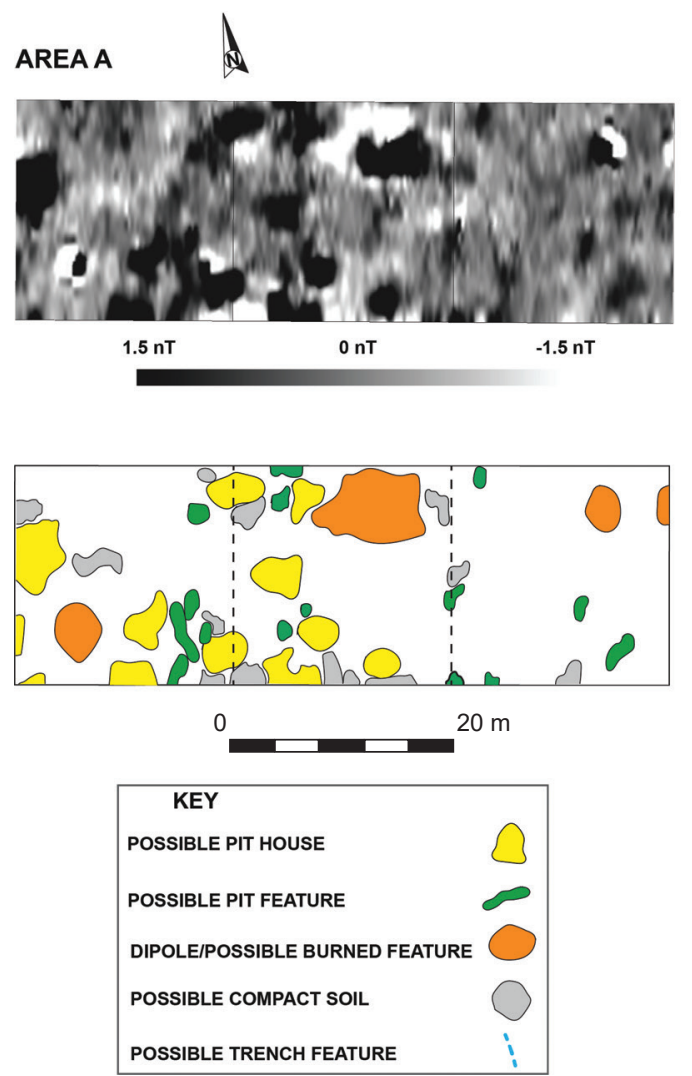
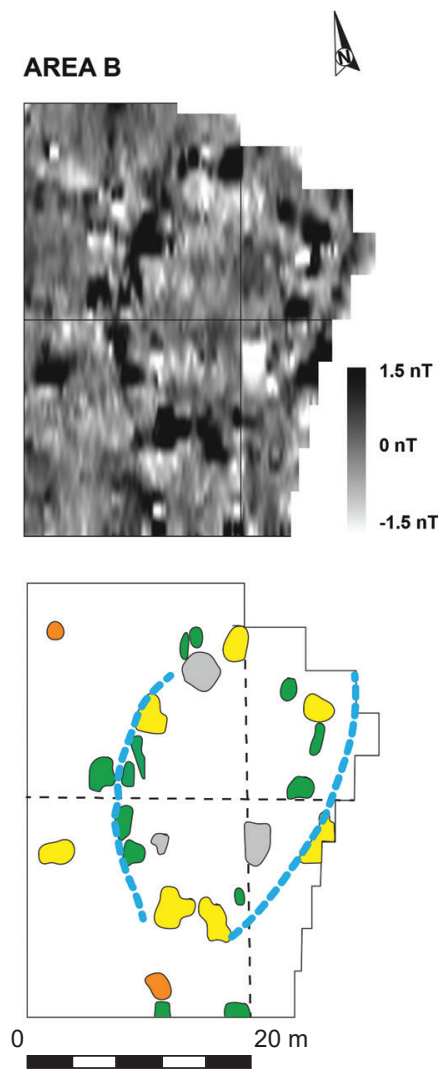

mapping is suitable for detection and investigation of earthen structures (ramparts, embankments, artificial terraces, turf building remains, barrows) and larger negative archaeological features (ditches, pits, etc.) (Bonsall et al., 2013; Wunderlich et al., 2015; Basar, 2018). Previous research indicates that low-frequency EM methods can also identify high resistance materials (e.g. walls, bricks, wooden structures) if their properties demonstrate sufficient contrast compared to the natural background (Ates, 2002; Basar, 2018).

Magnetic susceptibility variations are equivalent to changes of the in-phase component (Simon et al., 2015). Mapping magnetic susceptibility on archaeological settlements and their surroundings can be useful for discovering features of potential archaeological interest (e.g. dwellings, furnaces and pits with slag or ceramic material) (Tabbagh, 1986). Even negative archaeological features, such as ditches, can be detected based on in-phase results, owing to the magnetic properties of sediments with which they are filled (Simpson et al., 2009; Basar, 2018).

Surveys with the low-frequency EM CMD Mini-Explorer method were conducted over a $20 \times 60 \mathrm{~m}$ area, which was selected according to the results of previous surveys with gradiometry (Figure 4, Area A; Figure 5; Figure 6). The instrument was set to the Hi depth (HCP) coil orientation allowing the three receiver coils (Rec $1-3)$ to acquire data within different maximum depth levels $(0.5 \mathrm{~m}, 1 \mathrm{~m}$ and $1.8 \mathrm{~m})$ (Bonsall et al., 2013). Measurements were taken manually in $0.5 \mathrm{~m}$ intervals across profiles positioned $0.5 \mathrm{~m}$ apart. The data were interpolated using the Minimum Curvature method and $0.25 \times 0.25 \mathrm{~m}$ resolution. Data processing included the following: de-spiking, edge correction algorithm, (vertical and horizontal) de-stripping and low pass filter.

\subsection{Soil magnetic susceptibility method}

In addition to the EM method discussed in the section above, we employed a magnetic susceptibility survey of surface soils in Area A (Figures 4 and 6) utilizing the same $20 \times 60 \mathrm{~m}$ grid. The instrument used to collect this data was a Bartington MS2 meter combined with a MS2K Surface Sensor probe. A small shovel probe (approximately $25 \mathrm{~cm}$ diameter and $15 \mathrm{~cm}$ in depth) was utilized for sampling to penetrate below the root level of the agricultural ground cover. Three readings were taken at each probed location. Data were downloaded to a laptop computer and a mean value was calculated for each sampled location. Data were then plotted using Golden Software Surfer 13 software. Magnetic susceptibility of the surface soils survey was completed as an exploratory method to see whether enhanced areas could be identified spatially across the horizontal plane of the site through analysis of surface soils only. It was expected that these data could represent enhanced soils associated with subsurface archaeological features and activity zones due to vertical movement of soils through agricultural tilling and other forms of bioturbation. Association of surface magnetic susceptibility with subsurface features would also provide a comparative framework for better understanding how artefacts collected through the pedestrian survey may relate spatially to subsurface archaeological features. 

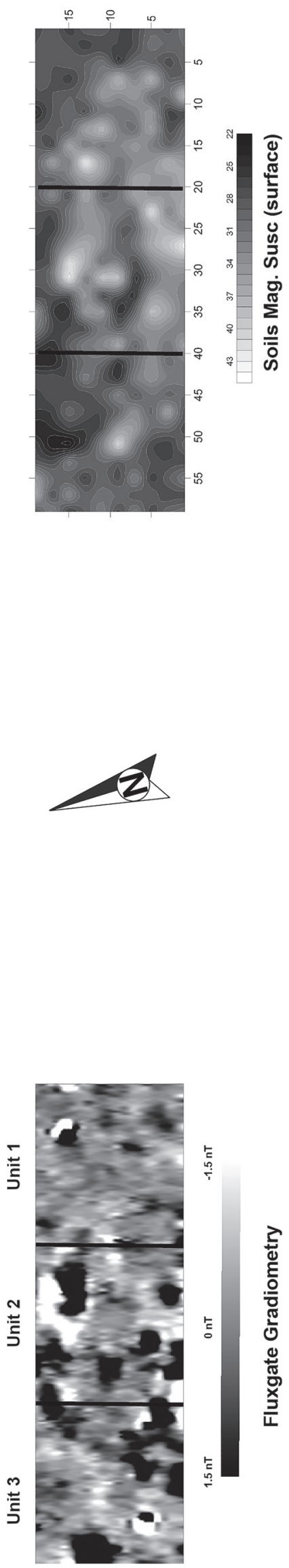
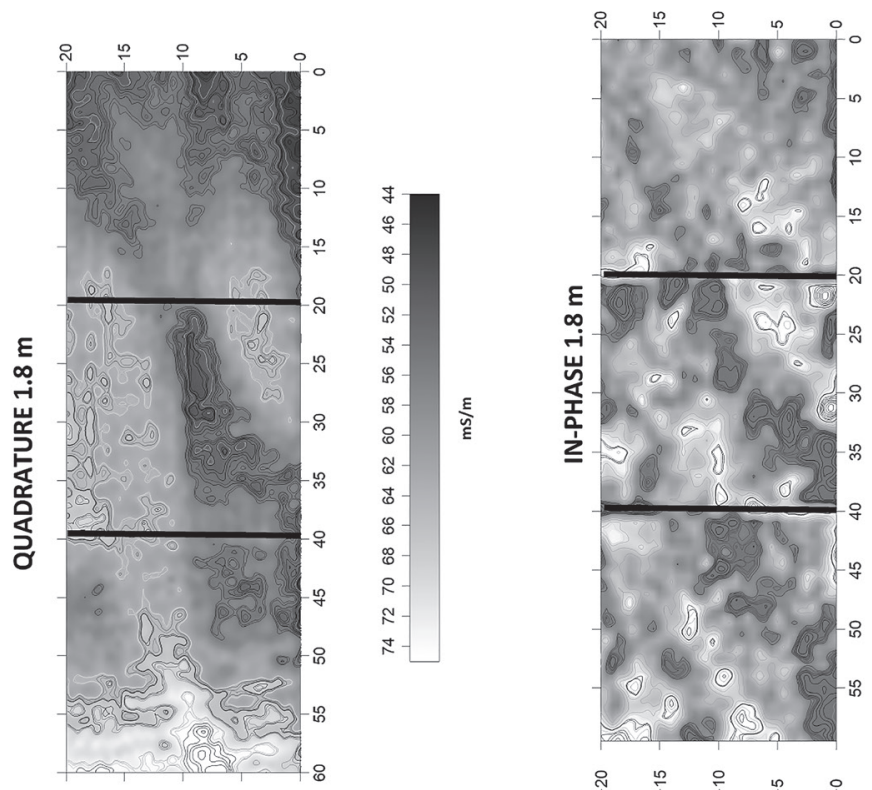

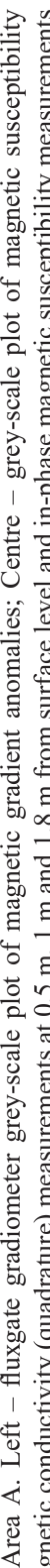
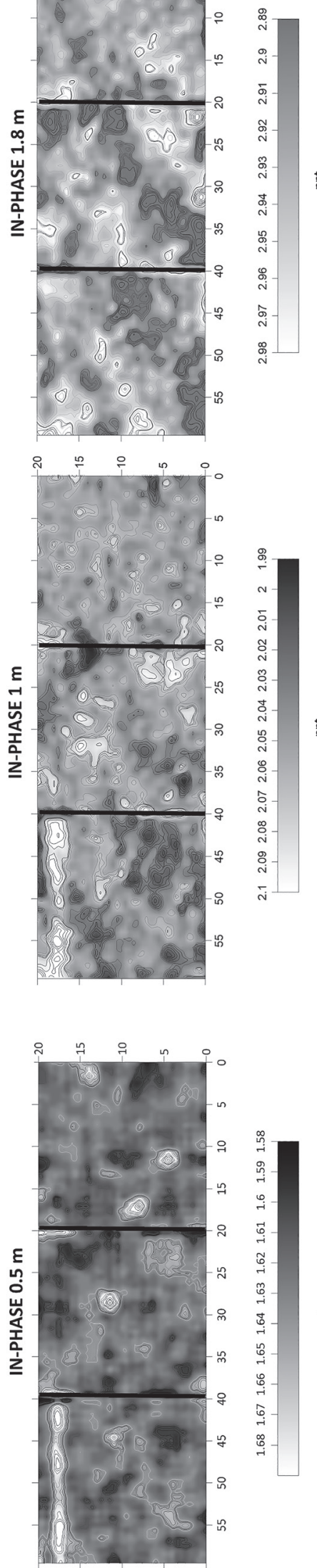

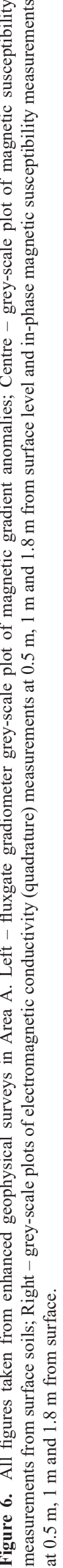




\section{Results and Discussion}

Multi-method geophysical survey, combined with pedestrian survey and artifact spatial analysis, has produced significant results at the Kneževac site. These methods work exceptionally well in tandem as they can provide two or more different forms of data that aid in supporting the interpretation of the other. For example, surface collection can provide an excellent proxy for overall site area size and more detailed spatial characterizations of activity zones, but it can be difficult to account for other processes that may affect the distribution of artifacts (e.g. agricultural cultivation and other topsoil post-depositional processes). Early Neolithic sites within Central Serbia have been difficult because of their small size and intrusive damage from later occupations. Although Kneževac is the smallest of the three Neolithic sites identified through pedestrian survey in the Gruža River valley, it still measured 6 ha and was a single component, with no Vinča occupation. Strikingly, the area around the site was devoid of artifacts of any period, except for a locale designated Zbegovište (tr. Refugium) to the northeast from which two green, glazed, Ottoman-period pottery sherds were recovered. One additional locale occurred in a $10 \times 10 \mathrm{~m}$ area adjacent to the spring below the site where a few pottery sherds dating to the Iron Age were identified. On the Early Neolithic Kneževac site itself, surface artifact distributions (Early Neolithic) show correspondence with subsurface features and other components of village layout (Figures 2 and 4).

The fluxgate gradiometry survey at Kneževac provided good results in distinguishing a range of monopolar and dipolar magnetic anomalies. These likely correspond to pit house, pit, trench, compact soils lenses associated with dwelling floors, and burned soils and/or high temperature anomalies associated with Early Neolithic occupation. The overall geological background of the site is magnetically "quiet" and anomalies in the range of \pm 1 to $5 \mathrm{nT}$ are easily identified (Figures 4 and 5). Although no targeted ground truthing has been completed at this site, the anomalies encountered and their spatial characteristics can be compared to excavated Early Neolithic sites within Central Serbia that have been excavated. As has been previously published for the site of Divostin, the spatial dimensions of excavated Starčevo pit houses, surface huts, and pit features fall within the approximate size of the magnetic anomalies identified at Kneževac (Table 1). Early Neolithic features excavated at Divostin also indicate that the overall dimensions of such features can vary substantially (Figure 7). As a result, it is difficult to distinguish with much certainty magnetic anomalies that are pits versus house pits, or surface hut features, without employing ground truthing. We have made these distinctions in Figures 4 and 5 based principally on the overall size and shape of the anomalies; however, future ground truthing is needed to verify these characterizations. Excavations at the Jaričište I site have also identified ovens associated with a Starčevo settlement and therefore we are not surprised by the identification through fluxgate gradiometry of potential burned areas or high temperature features at Kneževac (Marić, 2013).

Our geophysics results also indicate that conductivity data (EM method) has a strong correlation with surface soil magnetic susceptibility measurements reflecting changes within the topsoil (Figure 6). The low magnetic susceptibility area in the middle part of the second grid (Unit 2) is marked as an elongated low conductivity area flanked by anomalies with high conductivity and high surface magnetic susceptibility. The western-most part of the survey exhibits an area of high conductivity distributed in a north-south direction. The same area shows predominantly low surface magnetic susceptibility. We should also note that the first receiver for in-phase data $(0.5 \mathrm{~m} \max )$ indicates noise in the data as a linear anomaly in the north-west corner of the survey area. This was due to a switch of operators using the instrument, which occurred during the survey (Figure 6, lower plots, Unit 3, in CMD Mini-Explorer data).

Overall, our results show strong positive correlations with both measurements of soil surface magnetic susceptibility and magnetic gradiometry. Anomalies in the eastern and central part of the survey area (Units 1 and 2) are observed in the results from all three methods, which suggests that archaeological material or debris with magnetic properties could be located close to the surface. The distribution of anomalies within the results of the in-phase component from the second and third receiver (maximum measurement depth $1-1.8 \mathrm{~m}$ ) is similar to the fluxgate gradiometry data (Figure 6). However, the bipolar anomalies overlap both with anomalies of high and low in-phase values. The shapes, sizes and orientation of the anomalies indicate that anomalies

Table 1. Comparative data on huts, houses, and pits associated with Starčevo stratigraphic levels at Divostin settlement. Source: McPherron and Srejovic, 1988; Tables 5.1 and 5.2.

\begin{tabular}{lcc}
\hline & \multicolumn{2}{c}{ Starcevo Huts (N=6) } \\
\cline { 2 - 3 } Min & Length (cm) & Width (cm) \\
Max & 220,0 & 150,0 \\
Mean & 680,0 & 480,0 \\
Std. Dev. & 481,7 & 306,7 \\
& 158,3 & 130,3 \\
\hline & Starcevo Houses (N=6) \\
\hline Min & Length (cm) & Width (cm) \\
Max & 400,0 & 50,0 \\
Mean & 800,0 & 500,0 \\
Std. Dev. & 481,7 & 306,7 \\
\hline & 158,3 & 130,3 \\
\hline Min & Starcevo Pits (N=25) \\
Max & Length (cm) & Width (cm) \\
Mean & 80,0 & 50,0 \\
Std. Dev. & 1054,0 & 470,0 \\
\hline
\end{tabular}




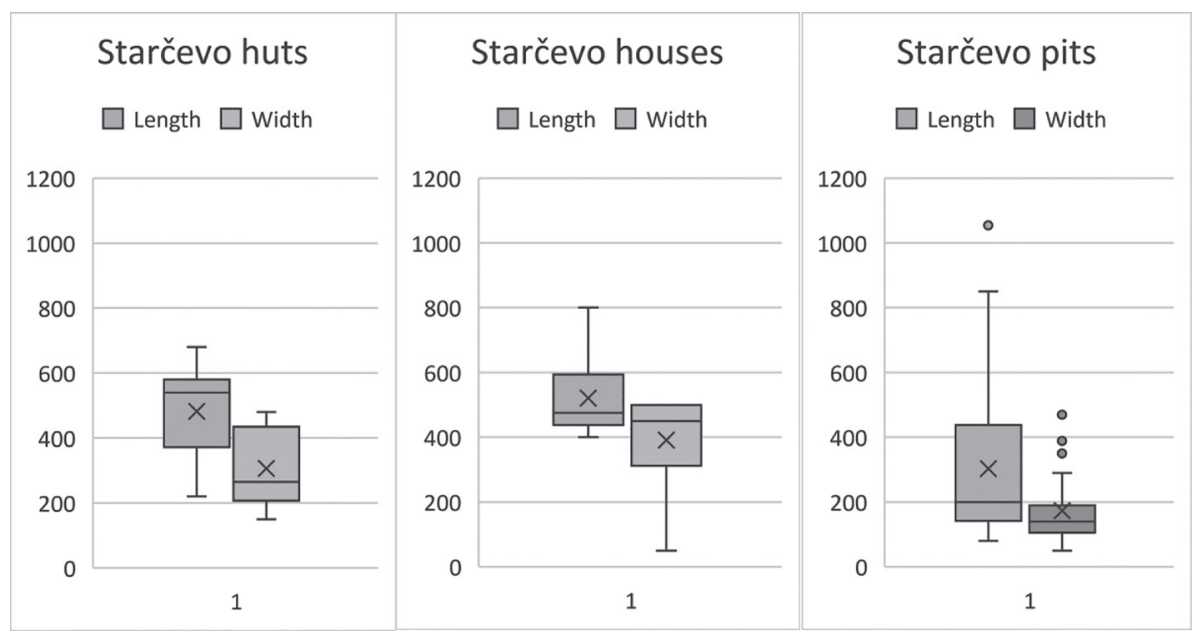

Figure 7. Box plots of Starčevo huts, houses and pits from Divostin settlement. Whiskers represent 2 standard deviations. Raw data were taken from McPherron and Srejovic, 1988; Tables 5.1 and 5.2. with low in-phase values could represent traces of Starčevo dwellings, whereas smaller anomalies in the immediate area can represent smaller adjacent areas of anthropogenic activity (e.g. waste pits, hearths or clay floors). It should be noted that there is a possibility that the results of the in-phase parameter have been affected by polarity shifts which are known to appear in the results of low-frequency EM methods (Bonsall et al., 2013). The overlap of low in-phase anomalies with high magnetic areas supports this interpretation; however, the causes of this phenomenon cannot yet be explained in more detail for this particular instrument. Further testing of these interpretations can be done by coring and examining the sediment with which the dwellings are filled. Recent studies with the low-frequency EM method indicate that pit house features may produce negative anomalies on the results of the in-phase parameter with higher conductivity values (Basar, 2018). One possibility is that the CMD MiniExplorer instrument is detecting the negative imprint of the anthropogenic structures that cut into the original ground surface of the archaeological activity area. Floor features associated with pit house structures may also exhibit compacted soil lenses, thus influencing the response of the conductivity measurement.

\section{Conclusion}

Results of the pedestrian and geophysical surveys at the site of Kneževac have been highly productive and represent the implementation of a novel multi-method approach to examining the spatial characteristics of Early Neolithic settlements in Central Serbia. These methods are comparable to other recent programs of research on Early Neolithic sites, for example, in Hungary and Romania as discussed above. Further research will be needed to ground truth the anomalies that have been identified through this research and to test current interpretations of the geophysical data. Important comparative work has been completed and published on Starčevo period architectural features at Divostin I and at the Jaričište I settlement. This will provide an important framework for further interpretations of the Kneževac settlement. There is still much to understand about the emergence of the Early Neolithic in Central Serbia and its chronological and spatial characteristics. An important first step in this process is the identification and rapid characterization of associated settlements. This paper has indicated that an approach that utilizes pedestrian survey, spatial artifact analysis, and multi-instrument geophysical prospection, can offer a highly effective way of identifying the surface distribution of artifacts and possible related subsurface features for further research and ground truthing. The results obtained at Kneževac indicate that this an important settlement for extended study as it may be one of the earliest villages of its type in this region of the Balkans that is undisturbed by later prehistoric and/or historic occupations.

\section{Acknowledgements}

The authors gratefully recognize the support of colleagues M. Grković and S. Perić and institutional support from the Institute for the Protection of Cultural Monuments (Kragujevac, Serbia) and the Institute of Archaeology of the Serbian Academy of Science (Belgrade, Serbia). We also gratefully acknowledge funding support from the National Science Foundation (DDRIG, BCS \#1741667), Institute for the Protection of Cultural Monuments, and the Dietrich School of Arts and Sciences, University of Pittsburgh.

\section{References}

ABDU, H., ROBINSON, D., and JONES, S., 2007. Comparing Bulk Soil Electrical Conductivity Determination Using the DUALEM-1S and EM38-DD Electromagnetic Induction Instruments. Soil Science Society of America Journal, 71, 189-196.

ASPINALL, A., GAFFNEY, C., and SCHMIDT, A., 2008. Magnetometry for Archaeologists. Plymouth: AltaMira Press.

ATES, A., 2002. Archaeogeophysical Investigations Around the Bilge Qagan Monument in Khosho Tsaidam, Mongolia. Archaeological Prospection, 9, 23-33. 
BÁNFFY, E., 2000. The Late Starčevo and the Earliest Linear Pottery Groups in Western Transdanubia. Documenta Praehistorica, 27, 173-185.

BÁNFFY, E., ed., 2013. The Early Neolithic in the Danube-Tisza Interfluve. Oxford: Archaeopress.

BASAR, P., 2018. Geofizikalne Raziskave Prazgodovinskih Najdišč $z$ Nizkofrekvenčno Elektromagnetno Metodo CMD Mini-Explorer. Unpublished thesis (MSc), University of Ljubljana.

BOGDANOVIĆ, M. 2004. Grivac: naselja protostarčevačke i vinčanske kulture. Kragujevac: Centar za naučna istraživanja SANU, Univerziteta u Kragujevcu.

BOGDANOVIĆ, M., 1983. Arheološka istraživanja na području centralne Srbije, "Staništa” Kragujevac, I/1983, br. 1, 9-26.

BOGDANOVIĆ, M., 2008. Grivac: Settlements of Proto-Starčevo and Vinča Culture. Kragujevac: Center for Scientific Research of Serbian Academy of Sciences and Arts and University of Kragujevac and National Museum of Kragujevac.

BONSALL, J., FRY, R., GAFFNEY, C., ARMIT, I., BECK, A. and GAFFNEY, V., 2013. Assessment of the CMD Mini-Explorer, a New Low-frequency Multi-coil Electromagnetic Device, for Archaeological Investigations. Archaeological Prospection, 20, 219-231.

BORIĆ, D., 2009. Absolute dating of metallurgical innovations in the Vinča Culture of the Balkans. In: T.L. Kienlin, and B.W. Roberts, eds. Metals and Societies: Studies in honour of Barbara S. Ottaway, Universitätsforschungen zur prähistorischen Archäologie, 169. Bonn: Habelt, pp. 191-245.

CARNEIRO, R.L., 1970. A theory of the origin of the state: Traditional theories of state origins are considered and rejected in favor of a new ecological hypothesis. Science, 169(3947), 733-738.

DRENNAN R.D., and PETERSON, C.E., 2011. Methods for Regiona Demographic Analysis in Settlement Patterns in the Chifeng Region. In: Chifeng International Collaborative Archaeological Research Project. Pittsburgh: Center for Comparative Archaeology.

EARLE, T.K., 1997. How chiefs come to power: The political economy in prehistory. Palo Alto: Stanford University Press.

FEINMAN, G.M., and NICHOLAS, L.M., 1990. At the margins of the Monte Alban state: Settlement patterns in the Ejutla Valley, Oaxaca, Mexico. Latin American Antiquity, 1(3), 216-246.

GARAŠANIN, D.,1954. Starčevačka kultura. Ljubljana: Univerza v Ljubljani, Arheoloski Seminar.

GAFFNEY, C., and GATER, J., 2003. Revealing the Buried Past: Geophysics for Archaeologists. Gloucestershire: Tempus.

GAVELA, B., 1951. Iskopavanja na paleolitskom lokalitetu Pećina pod Jerininim brdom u Gracu kod Kragujevca. Glasnik SANU, 3(2), Beograd: SANU

GREENFIELD, H.J., and LAWSON, K.S., 2018. Defining activity areas in the Early Neolithic (Starčevo-Criş) of southeastern Europe: A spatial analytic approach with ArcGIS at Foeni-Salaş (southwest Romania). Quaternary International, 539, 4-28.
HIRTH, K., 1980. Eastern Morelos and Teotihuacan: a settlement survey. Nashville: Vanderbilt University.

KAVAMME, K., JOHNSON, J., and HALEY, B., 2006. Multiple Methods Surveys: Case Studies. In: J. Johnson, ed. Remote Sensing in Archaeology: An Explicitly North American Perspective. Tuscaloosa: The University of Alabama Press, pp. 251-267.

KOČIĆ, M. 2019, Emergence of Social Complexity and Community Building in the Late Neolithic (5400-4600 cal. BCE) of the Central Balkans. Unpublished Thesis (PhD), University of Pittsburgh.

KUIJT, I., ed., 2006. Life in Neolithic farming communities: social organization, identity, and differentiation. Berlin: Springer Science \& Business Media.

MACNEISH, R.S., FOWLER, M.L., COOK, A.G., PETERSON, F.A., NELKEN-TERNER, A. and NEELY, J., 1975. Excavations and Reconnaissance. The Prehistory of the Tehuacan Valley, vol. 5, Austin and London: University of Texas Press.

MARIĆ, M., 2013. Zaštitna arheološka istraživanja na lokalitětu Jaričiště 1. In: V. Filipović, and D. Antonović, eds. Rezulteti novih arheoloških istraživanja u Severozapadnoj Srbiji i susednim těritorijama. Srpsko Arheološko Društvo.

MCPHERRON, A., and SREJOVIĆ, D., 1988. Divostin and the Neolithic of central Serbia. Vol. 1. Pittsburgh: University of Pittsburgh.

PERIĆ, S., 2016. The Neolithic in the Middle Morava Valley. Vol. 2. Arheološki Institut SANU.

SIMON, F.-X., SARRIS, A., THIESSON, J. and TABBAGH, A., 2015. Mapping of Quadrature Magnetic Susceptibility/Magnetic Viscosity of Soils by Using Multi-frequency EMI. Journal of Applied Geophysics, $120,36-47$.

SIMPSON, D., MEIRVENNE, M., SAEY, T., VERMEERSCH, H., BOURGEOIS, J., LEHOUCK, A., COCKX, L., and VITHARANA, U., 2009. Evaluating the Multiple Coil Configurations of the EM38DD and DUALEM-21S Sensors to Detect Archaeological Anomalies. Archaeological Prospection, 16, 91-102.

STANKOVIĆ, S., and LEKOVIĆ, V., 1994. Neolithic Settlement at Blagotin. Glasnik Srpsko Arheološkog Društva, 9, 177-179.

TABBAGH, A., 1986. Applications and Advantages of the Slingram Electromagnetic Method for Archaeological Prospecting. Geophysics, $51,576-584$.

THIESSON, J., DABAS, M. and FLAGEUL, S., 2009. Detection of Resistive Features Using Towed Slingram Electromagnetic Induction Instruments. Archaeological Prospection, 16, 103-109.

WUNDERLICH, T., WILKEN, D., ANDERSEN, J., RABBEL, W., ZORI, D., KALMRING, S., and BYOCK, J., 2015. On the Ability of Geophysical Methods to Image Medieval Turf Buildings in Iceland. Archaeological Prospection, 22, 171-186. 
